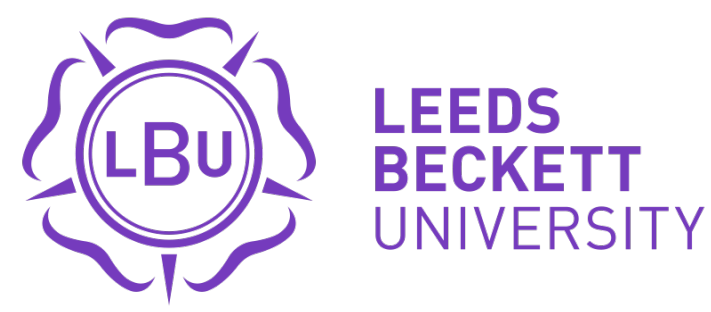

Citation:

Costello, NB and McKenna, J and Sutton, L and Deighton, K and Jones, B (2017) Case Study: Using Contemporary Behaviour Change Science to Design and Implement an Effective Nutritional Intervention within Professional Rugby League. International Journal of Sport Nutrition and Exercise Metabolism. ISSN 1526-484X DOI: https://doi.org/10.1123/ijsnem.2017-0298

Link to Leeds Beckett Repository record:

https://eprints.leedsbeckett.ac.uk/id/eprint/4569/

Document Version:

Article (Accepted Version)

The aim of the Leeds Beckett Repository is to provide open access to our research, as required by funder policies and permitted by publishers and copyright law.

The Leeds Beckett repository holds a wide range of publications, each of which has been checked for copyright and the relevant embargo period has been applied by the Research Services team.

We operate on a standard take-down policy. If you are the author or publisher of an output and you would like it removed from the repository, please contact us and we will investigate on a case-by-case basis.

Each thesis in the repository has been cleared where necessary by the author for third party copyright. If you would like a thesis to be removed from the repository or believe there is an issue with copyright, please contact us on openaccess@leedsbeckett.ac.uk and we will investigate on a case-by-case basis. 


\section{Case Study: Using Contemporary Behaviour Change Science to Design and Implement an Effective Nutritional Intervention within Professional Rugby League}

5

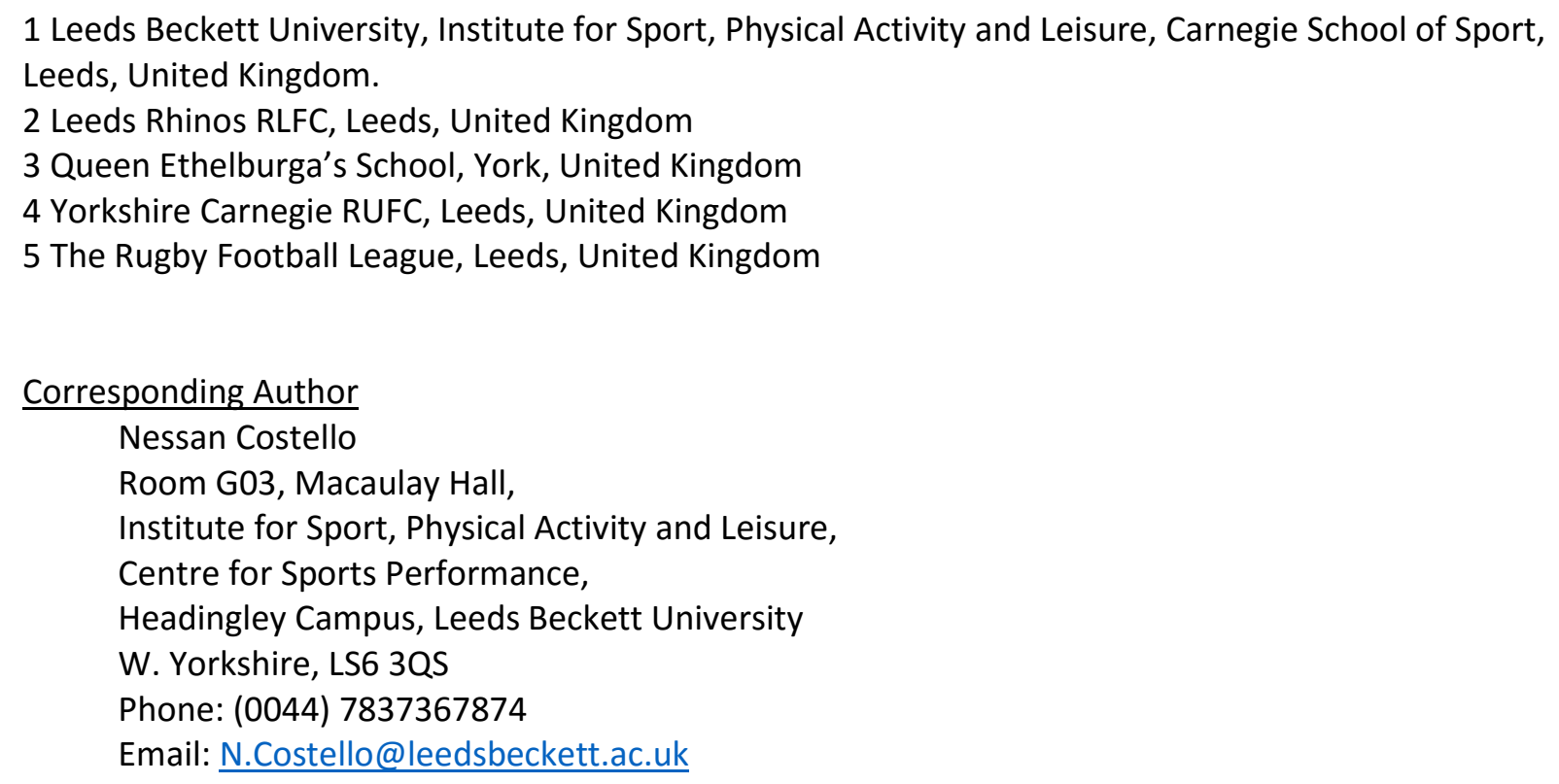




\section{Abstract}

Designing and implementing successful dietary intervention is integral to the role of sport nutrition professionals as they attempt to positively change the dietary behaviours of athletes. Highperformance sport is a time-pressured environment where immediate results can often supersede pursuit of the most effective evidence-based practice. However, efficacious dietary intervention necessitates comprehensive, systematic and theoretical behavioural design and implementation if the habitual dietary behaviours of athletes are to be positively changed. Therefore, this case study demonstrates how the Behaviour Change Wheel was used to design and implement an effective nutritional intervention within professional rugby league. The eight-step intervention targeted athlete consumption of a high quality dietary intake of $25.1 \mathrm{MJ}$ each day, to achieve an overall body mass increase of $5 \mathrm{~kg}$ across a twelve-week intervention period. The Capability, Opportunity, Motivation-Behaviour model and APEASE criteria were used to identify population-specific intervention functions, policy categories, behaviour change techniques and modes of intervention delivery. The resulting intervention was successful, increasing the average daily energy intake of the athlete to $24.5 \mathrm{MJ}$, which corresponded in a $6.2 \mathrm{~kg}$ body mass gain. Despite consuming $0.6 \mathrm{MJ}$ less per day than targeted, secondary outcome measures of diet quality, strength, body composition and immune function all substantially improved, supporting a sufficient energy intake and the overall efficacy of a behavioural approach. Ultimately, the Behaviour Change Wheel provides sport nutrition professionals with an effective and practical step-wise method via which to design and implement effective nutritional interventions for use within high-performance sport.

Keywords: Behaviour Change Wheel, Nutrition, Sports Nutrition 


\section{The Athlete}

72 The athlete was an eighteen-year-old professional male adolescent RL positional centre, who had

73 recently signed a senior contract with a European Super League club. He was required to increase his

74 body mass (BM) to $90 \mathrm{~kg}$ before joining the first team squad. This required a $5.6 \mathrm{~kg}$ increase over a

75 twelve-week intervention period. The athlete was susceptible to illness and had missed a combined

\section{Introduction}

Designing and implementing successful dietary intervention is integral to the role of sport nutrition professionals as they attempt to positively change the dietary behaviours of athletes. High-performance sport is a time-pressured environment where necessity for immediate results can often supersede pursuit of the most effective evidence-based practice (Coutts, 2017). This is apparent within contemporary dietary intervention, which lacks comprehensive, theoretical or systematic behavioural design and implementation (Atkins \& Michie, 2015). Instead, current dietary approaches within high performance sport are based upon fast, implicit, common sense models (Michie et al., 2009), consistently shown to result in less effective intervention (Craig et al., 2008). Evidently, novel approaches are required that provide both the scientific rigour and ease of application required for nutritional interventions to be successful within the challenging environment of professional sport (Jones et al., 2017).

The purpose of this case study was to demonstrate how the Behaviour Change Wheel (BCW; Michie et al., 2014) was used to design and implement a successful nutritional intervention aimed at increasing the BM of a professional male adolescent rugby league (RL) player, herein referred to as "the athlete". total of 22 training days over the last five months. Previous nutritional interventions had failed to result 
77 in substantial BM gains. Written informed consent was provided and ethics approval granted by Leeds

78 Beckett University, UK.

Athlete Assessment

\section{Anthropometric and Strength Assessment}

82 Anthropometric and strength characteristics were assessed at baseline and at the end of the twelve-

83 week intervention period. Changes in body composition were assessed by dual-energy X-ray

84 absorptiometry scans (DXA, Lunar iDXA, GE Medical Systems, UK) and sum of eight skinfold assessments

85 following standard procedures (Jones et al., 2017). Strength was assessed via three-repetition

86 maximums (3-RMs) as previously reported (Cronin \& Hansen, 2005). Pre-and post-intervention values

87 are presented in Table 1.

Dietary Assessment

89 Dietary intake was measured at baseline and at the end of the twelve-week intervention period via

90 Snap-N-Send, a valid and reliable dietary assessment tool (Costello et al., 2017a; Costello et al., 2017b).

91 The four-day assessment period included two weekdays and two weekend days (Friday-Monday). Data

92 were analysed using dietary analysis software (Nutritics, Version 3.06, Dublin, Ireland). Pre- and post-

93 intervention dietary intakes are presented in Table 2 and Appendix 1.

\section{Total Energy Expenditure Assessment}

95 Resting metabolic rate (RMR) was assessed using an on-line gas analyser (Metalyzer 3BR3, Cortex,

96 Leipzig, Germany) one day prior to the start of the total energy expenditure (TEE) assessment, as

97 outlined by Compher et al. (2006). TEE was assessed over a two-week pre-season period via doubly

98 labelled water (DLW), the literature gold standard (Westerterp, 2017). The assessment period included 
117 intervention outcome behaviourally. As such, the outcome cannot be for the athlete to gain BM, as this

118 is not a behaviour. Correct application of this first step is essential. To drive successful dietary behaviour

ten training and four rest days. Measured RMR was 14.7 MJ and average TEE was 22.4 MJ.day ${ }^{-1}$ across

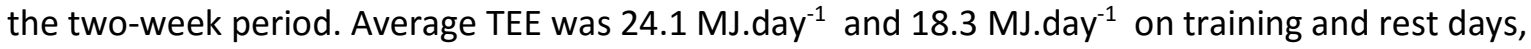
respectively.

\section{INSERT TABLE 1 \& 2 HERE}

\section{Design and Implementation of the Nutritional Intervention}

The Behaviour Change Wheel is a practical eight-step theory of behaviour change (Michie et al., 2014).

The core of the wheel incorporates a model of behaviour known as the COM-B (Michie et al., 2011), which identifies the sources of behaviour that are important for intervention. It states that an individual requires Capability (C), Opportunity (O) and Motivation (M) to perform a Behaviour (B). Surrounding the COM-B are nine intervention functions (Education; Persuasion; Incentivisation; Coercion; Training;

Restriction; Environmental Restructuring; Modelling; Enablement) and seven policy categories (Communication/Marketing; Guidelines; Fiscal Measures; Regulation; Legislation; Environmental/Social Planning; Service Provision) (Michie et al., 2014). Further information regarding the nine intervention functions and seven policy categories can be found in Michie et al. (2014).

Step 1: Define the Outcome in Behavioural Terms - The first step of the BCW involves describing the change the intervention has to target a behavioural outcome. From baseline data, the athlete consumed 16.7 MJ.day ${ }^{-1}$ and expended 22.4 MJ.day ${ }^{-1}$. This represented an estimated 5.9 MJ.day $\mathrm{Meficit}^{-1}$ 
121 supporting observed symptoms characteristic of relative energy deficiency in sport (Mountjoy et al.,

$1222014,2015)$. To increase BM by the desired $5.6 \mathrm{~kg}$, the athlete needed to gain $0.5 \mathrm{~kg}$ each week and

123 therefore consume a daily energy surplus of approximately 2.1 MJ. Accordingly, a suitably defined

124 behavioural intervention targeted athlete consumption of $25.1 \mathrm{MJ}$ of high quality foodstuffs each day

125 for the following twelve weeks.

127 Step 2: Select A Target Behaviour(s) - Behaviours are part of a dynamic and interactive system, they do not occur in isolation (Atkins \& Michie, 2015). Therefore, a long list of all the potential behaviours that may affect the ability of the athlete to consume $25.1 \mathrm{MJ}$ each day was developed, drawing upon relevant literature (Birkenhead \& Slater, 2015). This list included detailed input from the athlete and significant others (i.e. parents). The list of potential behaviours was then systematically shortened.

132 Criteria developed by Michie et al. (2014) was used to identify which behaviour(s) to target: Likely 133 Impact, Ease of Implementation, Likely Spillover (i.e. collateral impact) and Ease of Measurement.

134 Applying these criteria resulted in the following five behaviours being identified;

1. Increase the knowledge of the athlete, and significant others, about the health, development and performance benefits of consuming a high quality dietary intake of $25.1 \mathrm{MJ}$ each day.

2. Increase the knowledge of the athlete, and significant others, about how to achieve a high quality dietary intake of $25.1 \mathrm{MJ}$ each day. This should specify what to eat, in what quantities and at what times.

3. Provide the athlete with free and discounted high-quality food and batch-tested supplements. athlete, significant others and head coach. 
5. Provide the athlete with regular, immediate and accessible support via the cellular network.

144 It is imperative practitioners apply appropriate time to consider all population-specific relevant

145 behaviours. Choosing the wrong key target behaviours at this stage will most likely result in an

146 unsuccessful dietary intervention.

147

148 Step 3: Specify The Targeted Behaviour(s) - The five identified behaviours were then contextualised in

149 appropriate detail, considering;

150 - Who needs to perform the behaviour?

151 - What does the person need to do differently to achieve the desired change?

152 - When will they do it?

153 - Where will they do it?

154 This specification is provided in Table 3.

Step 4: Identify What Needs to Change - The COM-B model was used to identify what needed to

159 change to ensure the behaviour(s) occurred. Specifically, did the athlete have both the physical and 160 psychological Capability, physical (i.e. environmental) and social (i.e. cultural) Opportunity and finally,

161 the reflective (i.e. evaluations and plans) and automatic (i.e. emotions and impulses) Motivation to

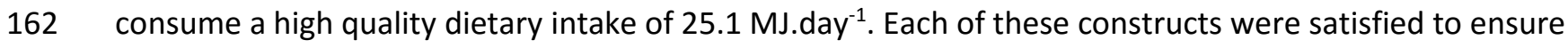
163 the overall behavioural outcome was successfully achieved (Michie et al., 2014). 
164 The COM-B behavioural analysis is identified in Table 3. All targeted behaviours performed by the sport

165 nutrition professional $(1,2,4$ \& 5) were hindered by physical Opportunity (i.e. environmental

166 restrictions). Like all competent practitioners, the nutritionist had both the Capability and Motivation to

167 perform the behaviours but was limited in his Opportunity to deliver them. Whereas the club (3), was

168 hindered in their reflective Motivation (i.e. evaluations and plans), not Capability or Opportunity, to 169 provide an academy player with first team free food or supplement privileges. Finally, the athlete (4)

170 was hindered by his physical Capability (i.e. not owning weighing scales) and automatic Motivation to 171 consume $25.1 \mathrm{MJ}^{\text {.day }}{ }^{-1}$ of high quality food stuffs.

172

173 Step 5: Identify Intervention Functions - Having made a behavioural diagnosis via the COM-B, the next 174 step was to build the intervention. Intervention functions are broad categories of means by which an 175 intervention can change behaviour. The APEASE criteria has been developed to support function 176 selection (Michie et al., 2014);

177 1. Is it Affordable?

$178 \quad 2 . \quad$ Is it Practical?

179

3. Will it be Effective/Cost-Effective?

The intervention function 'coercion' (i.e. create expectation of punishment) was chosen to intervene on the physical Opportunity of the sport nutrition professional and reflective Motivation of the club. For example, the athlete received sanction if he did not attend organised nutrition sessions, whereas, it negatively impacted the club to not provide the athlete with the resources necessary for optimal 
187 development. The intervention functions 'environmental restructuring' (i.e. provide a weighing scale)

188 and 'enablement' (i.e. provide free high quality food stuffs) were chosen to increase the physical

189 Capability and automatic Motivation of the athlete, respectively.

191 Step 6: Identify Policy Categories - Seven policy categories sit on the outer layer of the BCW (Michie et 192 al., 2014). Policies identify how specified intervention functions will be delivered. For example, the 193 intervention function 'enablement' was appropriately delivered via 'regulation' (i.e. establishing rules to 194 ensure the athlete remembered to report their fasted BM bi-weekly). The intervention functions 195 'environmental restructuring' and 'coercion' were delivered via 'regulation' and 'legislation', 196 respectively.

Step 7: Identify Behaviour Change Techniques - Behaviour change techniques (BCTs) are the 'active 199 ingredients' within an intervention, designed to bring about the desired behavioural change (Michie et 200 al., 2014). There are 93 consensually agreed BCTs (Michie et al., 2011), which were systematically 201 chosen in response to identified intervention functions and contextualised via the APEASE criteria. 202 Examples utilised within this nutritional intervention include, 'goal setting' (i.e. to consume six meals consistently each day) and 'self-monitoring of behaviour' (i.e. self-reported fasted BM assessments).

Step 8: Identify Mode of Delivery - The final stage of the BCW involves identifying how each aspect of the intervention will be implemented. All available options were contextualised and systematically 207 selected via the APEASE criteria. This intervention utilised group and individual face-to-face delivery (i.e. 208 coercion via legislation - contractual agreement between the club and significant others outlining the 
209 requirement for the athlete to attend all nutrition sessions) and group and individual cellular contact

210 (i.e. enablement via regulation - the athlete must respond to WhatsApp reminders from the sport

211 nutrition professional when completing his self-reported BM assessment).

213 Outcome of the Intervention

214 The athlete increased his BM by $6.2 \mathrm{~kg}$ across the twelve-week intervention, exceeding the targeted $5 \mathrm{~kg}$ 215 gain by $24 \%$. As such, the intervention was deemed successful. BM changes consisted of a $4.8 \mathrm{~kg}$ and 1.6 $216 \mathrm{~kg}$ increase in FFM and fat mass, respectively, representing only a $0.2 \%$ increase in body fat. Such

217 changes evidence the quality of dietary intake (Appendix 1), which included a reduction in average 218 alcohol and free-sugar intakes by $18 \mathrm{~g}$ and $120 \mathrm{~g}$ per day, respectively. The athlete reported no symptoms 219 of gastro-intestinal discomfort throughout the assessment period. Nutritional improvements occurred in 220 conjunction with a notable $305 \mathrm{~N}$ improvement in the mid-thigh pull, a surrogate measure of absolute 221 strength (McGuigan \& Winchester, 2008). Finally, the athlete also reported no symptoms of illness 222 across the intervention period, attending all 61 training sessions. Collectively, these results suggest that 223 the average $24.5 \mathrm{MJ}$ daily energy intake of the athlete, although $0.6 \mathrm{MJ}$ less than targeted, was sufficient 224 to meet energy availability demands (Mountjoy et al., 2014, 2015).

\section{Conclusion and Practical Considerations}

227 Delivering successful dietary intervention is integral to the role of sport nutrition professionals. The BCW 228 represents an easy and practical way to design and implement more efficacious dietary intervention 229 within high-performance sport (Atkins \& Michie, 2015). Despite this, athletes are individuals and will 230 behave uniquely in response to intra-personal, inter-personal and external factors (Ogden, 2016). 
231 Therefore, practitioners are encouraged to perform deliberate practise before real-life application,

232 taking advantage of the considerable resources available to guide more successful implementation.

233

234

235 


\section{Acknowledgments}

The authors would like to thank the athlete for his involvement in the intervention, Matt Ireton and Brian Olroyd for their efforts during data collection. All authors contributed to the study design, data collection, data analysis and writing of the manuscript. Results are presented clearly, honestly, and without fabrication, falsification, or inappropriate data manipulation. The authors have no conflicts of interest to declare. 


\section{References}

Atkins, L., \& Michie, S. (2015). Designing interventions to change eating behaviours. Proc Nutr Soc, 74(2), 164-170.

Birkenhead, K. L., \& Slater, G. (2015). A Review of Factors Influencing Athletes' Food Choices. Sports Medicine, 45(11), 1511-1522.

Compher, C., Frankenfield, D., Keim, N., \& Roth-Yousey, L. (2006). Best practice methods to apply to measurement of resting metabolic rate in adults: a systematic review. J Am Diet Assoc, 106(6), 881-903.

Costello, N., Deighton, K., Dyson, J., McKenna, J., \& Jones, B. (2017). Snap-N-Send: A valid and reliable method for assessing the energy intake of elite adolescent athletes. European Journal of Sport Science, 17(8), 1044-1055.

Costello N, McKenna J, Deighton K, Jones B. Commentary: Snap-N-Send: A Valid and Reliable Method for Assessing the Energy Intake of Elite Adolescent Athletes. Frontiers in Nutrition 2017; 4.

Coutts, A. J. 2016. Working Fast and Working Slow: The Benefits of Embedding Research in High Performance Sport. Int J Sports Physiol Perform, 11, 1-2.

Coutts, A. J. 2017. Challenges in Developing Evidence-Based Practice in High-Performance Sport. International Journal of Sports Physiology and Performance, 12, 717-718.

Craig, P., Dieppe, P., Macintyre, S., Michie, S., Nazareth, I., \& Petticrew, M. (2008). Developing and evaluating complex interventions: the new Medical Research Council guidance. BMJ, 337.

Cronin, J. B. \& Hansen, K. T. 2005. Strength and power predictors of sports speed. J Strength Cond Res, $19,349-57$.

Jones, B., Till, K., Emmonds, S., Hendricks, S., Mackreth, P., Darrall-Jones, J., Roe, G., Mcgeechan, S. I., Mayhew, R., Hunwicks, R., Potts, N., Clarkson, M. \& Rock, A. 2017. Accessing off-field brains in sport; an applied research model to develop practice. British Journal of Sports Medicine.

Jones, B., Till, K., Roe, G., O'hara, J., Lees, M., Barlow, M. J. \& Hind, K. 2017. Six-year body composition change in male elite senior rugby league players. J Sports Sci, 1-6.

McGuigan, M. R., \& Winchester, J. B. (2008). The Relationship Between Isometric and Dynamic Strength in College Football Players. Journal of Sports Science \& Medicine, 7(1), 101-105.

Michie, S., Fixsen, D., Grimshaw, J. M., \& Eccles, M. P. (2009). Specifying and reporting complex behaviour change interventions: the need for a scientific method. Implementation Science : IS, 4, 40-40.

Michie, S., Atkins, L., \& West, R. (2014). The behaviour Change Wheel: A Guide to Designing Interventions, 1st edn. London: Silverback

Michie, S., van Stralen, M. M., \& West, R. (2011). The behaviour change wheel: A new method for characterising and designing behaviour change interventions. Implementation Science : IS, 6, 4242.

Michie S, Richardson M, Johnston M, Abraham C, Francis J, Hardeman W, Eccles MP, Cane J, Wood CE. The behavior change technique taxonomy (v1) of 93 hierarchically clustered techniques: building an international consensus for the reporting of behavior change interventions. Annals of behavioral medicine : a publication of the Society of Behavioral Medicine 2013; 46: 81-95.

Mountjoy, M., Sundgot-Borgen, J., Burke, L., Carter, S., Constantini, N., Lebrun, C., . . Ljungqvist, A. (2014). The IOC consensus statement: beyond the Female Athlete Triad-Relative Energy Deficiency in Sport (RED-S). British Journal of Sports Medicine, 48(7), 491-497. 
Mountjoy, M., Sundgot-Borgen, J., Burke, L., Carter, S., Constantini, N., Lebrun, C., . . Ljungqvist, A. (2015). Authors' 2015 additions to the IOC consensus statement: Relative Energy Deficiency in Sport (RED-S). British Journal of Sports Medicine, 49(7), 417-420.

Ogden J. Celebrating variability and a call to limit systematisation: the example of the Behaviour Change Technique Taxonomy and the Behaviour Change Wheel. Health psychology review 2016; 10 : 245-250.

Till, K., Jones, B., \& Geeson-Brown, T. (2016). Do physical qualities influence the attainment of professional status within elite 16-19 year old rugby league players? J Sci Med Sport, 19(7), 585589.

Till, K., Scantlebury, S., \& Jones, B. (2017). Anthropometric and Physical Qualities of Elite Male Youth Rugby League Players. Sports Medicine. doi:10.1007/s40279-017-0745-8

Westerterp, K. R. (2017). Doubly labelled water assessment of energy expenditure: principle, practice, and promise. European Journal of Applied Physiology, 117(7), 1277-1285. 
Table 1. Anthropometric and Strength Assessment Pre-and Post-Intervention

\begin{tabular}{l|c|c|c}
\hline Athlete Characteristic & Baseline & Post-Intervention & Percent Change (\%) \\
\hline Body mass (kg) & 84.6 & 90.8 & 7.3 \\
Lean-tissue mass (kg) & 64.3 & 69.0 & 7.3 \\
Bone mineral content (kg) & 3.2 & 3.3 & 3.1 \\
Fat mass (kg) & 17.1 & 18.5 & 8.2 \\
Body Fat Percentage (\%) & 20.2 & 20.4 & 1 \\
ISAK sum of eight skinfolds (mm) & 83 & 90 & 8.4 \\
\hline Strength Assessment (3RM) & Baseline & Post-Intervention & Percent Change (\%) \\
\hline Bench press (kg) & 112.5 & 120 & 6.7 \\
Prone row (kg) & 86.5 & 92.5 & 6.9 \\
Military press (kg) & 60 & 65 & 8.3 \\
Back squat (kg) & 125 & 135 & 8.0 \\
Mid-thigh pull (N) & 3,242 & 3,547 & 9.4 \\
\hline
\end{tabular}

Table 2. Average Daily Dietary Intake Pre-and Post-Intervention

\begin{tabular}{l|c|c|c}
\hline Average Dietary Intake & Baseline & Post-Intervention & Percent Change (\%) \\
\hline Carbohydrate (g) & 440 & 645 & 46.6 \\
Free sugar (g) & 178 & 58 & -67.4 \\
Fat (g) & 142 & 213 & 50.0 \\
Saturated (g) & 42 & 84 & 100.0 \\
Protein (g) & 142 & 331 & 133.1 \\
Alcohol (g) & 18 & 0 & -100 \\
Total Energy Intake (MJ) & 16.7 & 24.5 & 46.7 \\
\hline
\end{tabular}


Table 3. Specification of the Target Behaviours and COM-B Behavioural Analysis

\begin{tabular}{|c|c|c|c|c|c|}
\hline Target Behaviour & Who & What & When & Where & $\begin{array}{l}\text { COM-B Behavioural } \\
\text { Analysis }\end{array}$ \\
\hline $\begin{array}{l}\text { 1. Increase the knowledge of the athlete, } \\
\text { and significant others, about the health, } \\
\text { development and performance benefits of } \\
\text { consuming a high quality dietary intake of } \\
25.1 \mathrm{MJ}(6,000 \mathrm{kcal}) \text { each day. }\end{array}$ & $\begin{array}{l}\text { sport and } \\
\text { exercise } \\
\text { nutritionist }\end{array}$ & $\begin{array}{l}\text { Oral presentation / written } \\
\text { information / infographics / other } \\
\text { support as required }\end{array}$ & $\begin{array}{l}\text { Start of twelve- } \\
\text { week intervention } \\
\text { / as required } \\
\text { throughout }\end{array}$ & $\begin{array}{l}\text { Club / appropriate social media } \\
\text { platforms for athlete (i.e. } \\
\text { WhatsApp), and significant others } \\
\text { (i.e. google drive, text, email) }\end{array}$ & $\begin{array}{l}\text { Physical Opportunity - Sport } \\
\text { and Exercise Nutritionist }\end{array}$ \\
\hline $\begin{array}{l}\text { 2. Increase the knowledge of the athlete, } \\
\text { and significant others, about how to } \\
\text { achieve a high quality dietary intake of } \\
25.1 \mathrm{MJ}(6,000 \text { kcal) each day. This should } \\
\text { specify what to eat, in what quantities and } \\
\text { at what times. }\end{array}$ & $\begin{array}{l}\text { sport and } \\
\text { exercise } \\
\text { nutritionist }\end{array}$ & $\begin{array}{l}\text { Oral presentation / written } \\
\text { information i.e. diet plan(s) \& } \\
\text { guide(s) / shopping list(s) / } \\
\text { infographics / accessible recipes / } \\
\text { other support as required }\end{array}$ & $\begin{array}{l}\text { Start of twelve- } \\
\text { week intervention } \\
\text { / as required } \\
\text { throughout }\end{array}$ & $\begin{array}{l}\text { Club / appropriate social media } \\
\text { platforms for athlete (i.e. } \\
\text { WhatsApp), and significant others } \\
\text { (i.e. google drive, text, email) }\end{array}$ & $\begin{array}{l}\text { Physical Opportunity - Sport } \\
\text { and Exercise Nutritionist }\end{array}$ \\
\hline $\begin{array}{l}\text { 3. Provide the athlete with free and } \\
\text { discounted high-quality food and batch- } \\
\text { tested supplements, as available to first } \\
\text { team athletes. }\end{array}$ & Club & $\begin{array}{l}\text { Free batch tested supplements } \\
\text { i.e. whey protein, creatine, mass } \\
\text { gainer / free meals around } \\
\text { training and competition i.e. } \\
\text { breakfast, pre-\& post-game } \\
\text { meals or snacks / snacks available } \\
\text { at 'food station' / cost price meat } \\
\text { bundles delivered to house / } \\
\text { discount on sponsored products } \\
\text { i.e. biltong }\end{array}$ & $\begin{array}{l}\text { Start of twelve- } \\
\text { week intervention } \\
\text { / as required } \\
\text { throughout }\end{array}$ & Club / home (delivered) & Reflective Motivation - Club \\
\hline $\begin{array}{l}\text { 4. Regularly assess the BM of the athlete. } \\
\text { Progress should be immediately relayed } \\
\text { back to him, significant others and the } \\
\text { head coach. }\end{array}$ & $\begin{array}{l}\text { Athlete \& } \\
\text { sport and } \\
\text { exercise } \\
\text { nutritionist }\end{array}$ & $\begin{array}{l}\text { Bi-weekly fasted weigh-in (self- } \\
\text { reported by athlete) / weekly } \\
\text { sum of } 8 \text { skinfolds (Sport and } \\
\text { Exercise Nutritionist)/ feedback } \\
\text { results (Sport and Exercise } \\
\text { Nutritionist) }\end{array}$ & $\begin{array}{l}\text { Monday \& } \\
\text { Thursday } \\
\text { mornings (weigh- } \\
\text { in) / Monday } \\
\text { mornings } \\
\text { (skinfolds) }\end{array}$ & $\begin{array}{l}\text { Club / appropriate social media } \\
\text { platforms for athlete (i.e. } \\
\text { WhatsApp), and significant others } \\
\text { (i.e. google drive, text, email) }\end{array}$ & $\begin{array}{l}\text { Physical Capability \& } \\
\text { Automatic Motivation - } \\
\text { Athlete } \\
\text { Physical Opportunity - Sport } \\
\text { and Exercise Nutritionist }\end{array}$ \\
\hline
\end{tabular}




\begin{tabular}{|c|c|c|c|c|c|}
\hline $\begin{array}{l}\text { 5. Provide the athlete with regular, } \\
\text { immediate and accessible support via the } \\
\text { cellular network. }\end{array}$ & $\begin{array}{l}\text { sport and } \\
\text { exercise } \\
\text { nutritionist }\end{array}$ & $\begin{array}{l}\text { Information, advice, knowledge / } \\
\text { prompts, cues, nudges / } \\
\text { feedback, encouragement / other } \\
\text { support as required }\end{array}$ & $\begin{array}{l}\text { As required } \\
\text { throughout }\end{array}$ & $\begin{array}{l}\text { Club / appropriate social media } \\
\text { platforms for athlete (i.e. } \\
\text { WhatsApp), and significant others } \\
\text { (i.e. google drive, text, email) }\end{array}$ & $\begin{array}{l}\text { Physical Opportunity - Sport } \\
\text { and Exercise Nutritionist }\end{array}$ \\
\hline
\end{tabular}




\begin{tabular}{|c|c|c|c|}
\hline \multicolumn{4}{|c|}{ Baseline - Week Day } \\
\hline \multicolumn{2}{|c|}{ Food or Drink } & Portion & Time of Intake \\
\hline \multicolumn{2}{|l|}{ Weetabix } & $80 \mathrm{~g}(\mathrm{x} 4)$ & 07:00 \\
\hline \multicolumn{2}{|l|}{ Skimmed Milk } & $270 \mathrm{ml}$ & \\
\hline \multicolumn{2}{|c|}{ Tea (skimmed milk and $x 1$ teaspoon sugar) } & $260 \mathrm{ml}$ & \\
\hline \multicolumn{2}{|l|}{ Crisps } & $45 g(x 1)$ & $10: 15$ \\
\hline \multicolumn{2}{|l|}{ Club Penguin } & $35 g(x 1)$ & \\
\hline \multicolumn{2}{|l|}{ Apple } & $152 \mathrm{~g}$ & \\
\hline \multicolumn{2}{|l|}{ Lucozade } & $380 \mathrm{ml}$ & \\
\hline \multicolumn{2}{|l|}{ Lasagne } & $290 \mathrm{~g}$ & $13: 30$ \\
\hline \multicolumn{2}{|l|}{ Oven Chips } & $180 \mathrm{~g}$ & \\
\hline \multicolumn{2}{|l|}{ Tomato Ketchup } & $24 \mathrm{~g}$ & \\
\hline \multicolumn{2}{|l|}{ Coke } & $330 \mathrm{ml}(x 1 \mathrm{can})$ & \\
\hline \multicolumn{2}{|c|}{ Tea (skimmed milk and $x 1$ teaspoon sugar) } & $260 \mathrm{ml}$ & 15:00 \\
\hline \multicolumn{2}{|c|}{ Digestive Chocolate Biscuits } & $64 g(x 4)$ & \\
\hline \multicolumn{2}{|l|}{ Powerade } & $500 \mathrm{ml}$ & During Training \\
\hline \multicolumn{2}{|l|}{ Chicken Breast } & $100 \mathrm{~g}(\mathrm{x} 1 \mathrm{small}$ breast $)$ & $20: 30$ \\
\hline \multicolumn{2}{|l|}{ Sweet Potato Fries } & $120 \mathrm{~g}$ & \\
\hline \multicolumn{2}{|l|}{ Orange Juice } & $300 \mathrm{ml}$ & \\
\hline \multicolumn{2}{|c|}{ Galaxy Chocolate Bar } & $42 \mathrm{~g}$ & \\
\hline \multicolumn{2}{|l|}{ Cheerio's } & $35 \mathrm{~g}$ & $11: 30$ \\
\hline \multicolumn{2}{|l|}{ Skimmed Milk } & $135 \mathrm{ml}$ & \\
\hline \multicolumn{2}{|c|}{ Tea (skimmed milk and $x 1$ teaspoon sugar) } & $260 \mathrm{ml}$ & \\
\hline \multicolumn{2}{|c|}{ Digestive Chocolate Biscuits } & $80 \mathrm{~g}(\mathrm{x} 5)$ & \\
\hline \multicolumn{4}{|c|}{ Daily Dietary Intake } \\
\hline Carbohydrate & (g) & 519 & \\
\hline Free sugar & (g) & 200 & \\
\hline Fat & (g) & 136 & \\
\hline Saturated & (g) & 51 & \\
\hline Protein & (g) & 159 & \\
\hline Alcohol & (MJ) & 0 & \\
\hline Total Energy In & (MJ) & 16.8 & \\
\hline
\end{tabular}

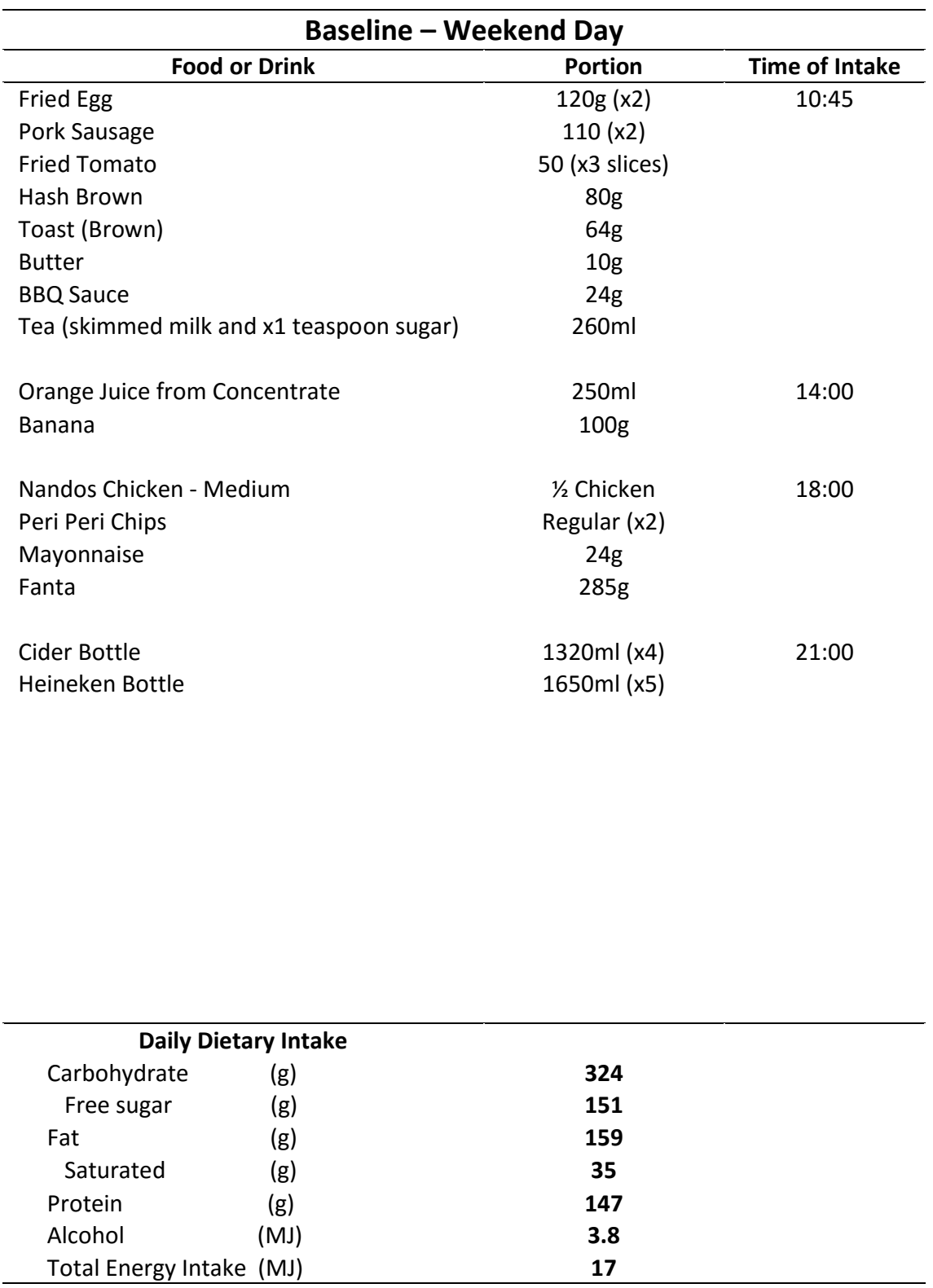




\section{Week 12 Dietary Intake.}

\section{Week 12 - Week Day}

\begin{tabular}{|c|c|c|}
\hline Food or Drink & Portion & Time of Intake \\
\hline Protein Weetabix & $100 \mathrm{~g}(\mathrm{x} 6)$ & 07:15 \\
\hline Full Fat Milk & $300 \mathrm{ml}$ & \\
\hline Mixed Nuts \& Raisins & $40 \mathrm{~g}$ & \\
\hline Banana & $100 \mathrm{~g}$ & \\
\hline Arla Quark Yogurt & $200 \mathrm{~g}$ & \\
\hline Fresh Orange Juice & $250 \mathrm{ml}$ & \\
\hline Fish Oil Capsule* & $2 g(x 2)$ & \\
\hline Tuna Melt with Salad & $250 \mathrm{~g}$ & 10:15 \\
\hline Biltong & 40g (x1) & \\
\hline Large Orange & $160 \mathrm{~g}$ & \\
\hline Club Penguin & 35g (x1) & \\
\hline Crisps & $45 \mathrm{~g}(\mathrm{x} 1)$ & \\
\hline Oasis Summer Fruits & $500 \mathrm{ml}$ & \\
\hline Chewing Gum & $3 g(x 1)$ & 11:15 \\
\hline Roast Beef & $150 \mathrm{~g}$ & 13:00 \\
\hline Roast Potatoes & $190 \mathrm{~g}$ & \\
\hline Carrot & $85 \mathrm{~g}$ & \\
\hline Cauliflower & $80 \mathrm{~g}$ & \\
\hline Gravy & $50 \mathrm{~g}$ & \\
\hline Full Fat Milk & $300 \mathrm{ml}$ & \\
\hline Soreen Malt Loaf & $60 \mathrm{~g}$ & Pre-Training \\
\hline Powerade & $500 \mathrm{ml}$ & During Training \\
\hline
\end{tabular}

\begin{tabular}{lcc} 
Mass Gainer* & $150 \mathrm{~g}$ (x3 Scoops) & Post-Training \\
Creatine* & $5 \mathrm{~g}$ & \\
Full Fat Milk & $568 \mathrm{ml}$ & $20: 00$ \\
& & \\
Lamb Chomps & $160 \mathrm{~g}$ & \\
Mash Potato & $250 \mathrm{~g}$ & \\
Runner Beans & $65 \mathrm{~g}$ & \\
Swede & $60 \mathrm{~g}$ \\
Gravy & $50 \mathrm{~g}$ & \\
Full Fat Milk & $300 \mathrm{ml}$ \\
Chocolate Mousse & $70 \mathrm{~g}$ \\
Strawberries & $65 \mathrm{~g}$ \\
& \\
Fage Greek Yogurt & $150 \mathrm{~g}$ \\
Honey & $20 \mathrm{~g}$ \\
Oats & $40 \mathrm{~g}$ \\
Frozen Berries & $60 \mathrm{~g}$ \\
Banana & $100 \mathrm{~g}$ \\
Nutella & $30 \mathrm{~g}$ \\
Full Fat Milk & $200 \mathrm{ml}$ \\
\hline Daily Dietary Intake & \\
Carbohydrate (g) & $\mathbf{6 7 4}$ \\
Free Sugar (g) & 65 \\
Fat (g) & $\mathbf{2 0 2}$ \\
Saturated (g) & $\mathbf{7 9}$ \\
Protein (g) & $\mathbf{3 5 2}$ \\
Alcohol (MJ) & $\mathbf{0}$ \\
Total Energy Intake (MJ) & $\mathbf{2 4 . 7}$ \\
\hline & \\
& \\
& & \\
& &
\end{tabular}




\begin{tabular}{|c|c|c|}
\hline \multicolumn{3}{|c|}{ Week 12 - Weekend Day } \\
\hline Food or Drink & Portion & Time of Intake \\
\hline Scrambled Egg & $180 \mathrm{~g}$ & 09:45 \\
\hline Heinz Beans & $175 \mathrm{~g}$ & \\
\hline Bacon & $105 \mathrm{~g}(\mathrm{x} 3)$ & \\
\hline Mushrooms & $80 \mathrm{~g}$ & \\
\hline Fried Tomato & $50 \mathrm{~g}$ (x3 slices) & \\
\hline Toast (White) & $60 \mathrm{~g}(\mathrm{x} 2)$ & \\
\hline Butter & $10 \mathrm{~g}$ & \\
\hline Full Fat Milk & $300 \mathrm{ml}$ & \\
\hline Fish Oil Capsule* & $2 g(x 2)$ & \\
\hline BLT & $165 \mathrm{~g}$ & $11: 30$ \\
\hline Weetabix On The Go Protein & $275 \mathrm{ml}$ & \\
\hline Crisps & $45 \mathrm{~g}$ & \\
\hline Banana & $100 \mathrm{~g}$ & \\
\hline Kit Kat & $22 \mathrm{~g}(\mathrm{x} 1)$ & \\
\hline Subway Foot Long - Meatball Marina & $300 \mathrm{~g}$ & 13:00 \\
\hline Tropicana Orange Juice & $330 \mathrm{ml}$ & \\
\hline Pear & $160 \mathrm{~g}$ & \\
\hline Arla Quark Yogurt & $200 \mathrm{~g}$ & \\
\hline Seeds & $14 \mathrm{~g}$ & \\
\hline Mixed Berries & $40 \mathrm{~g}$ & \\
\hline Oasis & $500 \mathrm{ml}$ & \\
\hline Salmon Fillet (x2) & $210 \mathrm{~g}$ & 20:00 \\
\hline Uncle Ben Microwave Rice & $100 \mathrm{~g}$ & \\
\hline
\end{tabular}

Asparagus $90 \mathrm{~g}$

Mixed Vegetables $\quad 80 \mathrm{~g}$

Full Fat Milk $300 \mathrm{ml}$

White Magnum 90g

Fage Greek Yogurt 150g

$20 \mathrm{~g}$

Honey

Kiwi

$60 \mathrm{~g}$

Banana 100g

Peanut Butter 45g

Full Fat Milk 200ml

Creatine* $5 \mathrm{~g}$

Daily Dietary Intake

Carbohydrate (g)

466

Free Sugar (g)

54

Fat (g)

268

Saturated (g)

104

Protein (g)

264

Alcohol (MJ)

0

Total Energy Intake (MJ) 